\title{
IMPLEMENTATION PATENT FOR APPLICATION WEB BASED CASE STUDI WWW.PUBLIKLAMPUNG.COM
}

Arie Setya Putra

0201028701

University Of Mitra Indonesia

ariesetyaputra@umitra.ac.id

\begin{abstract}
Hak Kekayaan Intelektual didefinisikan sebagai suatu perlindungan hukum yang diberikan oleh Negara kepada seseorang dan atau sekelompok orang ataupun badan yang ide dan gagasannya telah dituangkan ke dalam bentuk suatu karya cipta (berwujud). Karya Cipta yang telah berwujud tersebut merupakan suatu hak individu dan atau kelompok yang perlu dilindungi secara hukum, apabila suatu temuan (inovasi) tersebut didaftarkan sesuai dengan persyaratan yang ada.

Karya cipta yang berwujud dalam cakupan kekayaan intelektual yang dapat didaftarkan untuk perlindungan hukum yaitu seperti karya kesusastraan, artistik, ilmu pengetahuan (scientific), pertunjukan, kaset, penyiaran audio visual, penemuan ilmiah, desain industri, merek dagang, nama usaha, dll.
\end{abstract}

Kata Kunci : UU No 31 Tahun 2000, Information Technology 


\section{A. INTRODUCTION}

Section Class Ke $\mathbf{n}$ membahas mengenai i cloud system ...dst tambahkan gambar untuk memperkuat penjelasan

Gunakan Minimal 600 kata )

\section{B. LITERATURE REVIEW}

Pembahasan umum Referensi terkait ....( minimal 150 kata )

C. RESULT

Hasil ....( minimal 150 kata )

D. CONCLUSION

Kesimpulan dari materi ini adalah ....( minimal 150 kata $)$

E. ACKNOWLEDGEMENT

University Of Indonesia University Of Mitra Indonesia Telkom University University Of Mellbourne Saitama University 


\section{F. REFERENCES}

[1] A. S. Putra, H. Sukri, and K. Zuhri, "Sistem Monitoring Realtime Jaringan Irigasi Desa (JIDES) Dengan Konsep Jaringan Sensor Nirkabel," IJEIS (Indonesian J. Electron. Instrum. Syst., vol. 8, no. 2, pp. 221-232.

[2] D. P. Sari, O. M. Febriani, and A. S. Putra, "Perancangan Sistem Informasi SDM Berprestasi pada SD Global Surya," in Prosiding Seminar Nasional Darmajaya, 2018, vol. 1, no. 1, pp. 289-294.

[3] A. S. Putra, "Paperplain: Execution Fundamental Create Application With Borland Delphi 7.0 University Of Mitra Indonesia," 2018.

[4] A. S. Putra, D. R. Aryanti, and I. Hartati, "Metode SAW (Simple Additive Weighting) sebagai Sistem Pendukung Keputusan Guru Berprestasi (Studi Kasus: SMK Global Surya)," in Prosiding Seminar Nasional Darmajaya, 2018, vol. 1, no. 1, pp. 85-97.

[5] A. S. Putra and O. M. Febriani, "Knowledge Management Online Application in PDAM Lampung Province," in Prosiding International conference on Information Technology and Business (ICITB), 2018, pp. 181-187.

[6] A. S. Putra, O. M. Febriani, and B. Bachry, "Implementasi Genetic Fuzzy System Untuk Mengidentifikasi Hasil Curian Kendaraan Bermotor Di Polda Lampung," SIMADA (Jurnal
Sist. Inf. dan Manaj. Basis Data), vol. 1, no. 1, pp. 21-30, 2018.

[7] A. S. Putra, "2018 Artikel Struktur Data, Audit Dan Jaringan Komputer," 2018.

[8] O. M. Febriani and A. S. Putra, "Sistem Informasi Monitoring Inventori Barang Pada Balai Riset Standardisasi Industri Bandar Lampung," J. Inform., vol. 13, no. 1, pp. 90-98, 2014. 